\title{
(Persistent) Organic pollutants in Germany: results from a pilot study within the 2015 moss survey
}

\author{
Annekatrin Dreyer ${ }^{1 *}$, Stefan Nickel ${ }^{2}$ and Winfried Schröder ${ }^{2}$
}

\begin{abstract}
Background: Since 1990, every 5 years, moss sampling is conducted within the European moss monitoring programme to assess the atmospheric deposition of airborne pollutants. Besides many other countries, Germany takes regularly part at these evaluations. Within the European moss monitoring 2015, more than 400 moss samples across Germany were taken according to a harmonized methodology for the assessment heavy metal and nitrogen input. In a pilot programme, eight of these sites were chosen for additional investigations on a broad range of organic contaminants to evaluate their accumulation in moss and thereby their presence in atmospheric deposition in Germany. Target compound classes comprised polycyclic aromatic hydrocarbons (PAH), polychlorinated dibenzodioxins and -furans (PCDD/F), dioxin-like and non-dioxin-like polychlorinated biphenyls (dl-PCB, ndl-PCB), polyfluorinated alkyl substances, classical flame retardants as well as emerging chlorinated and brominated flame retardants. In total, 120 target compounds were analysed. For some analytes, comparisons of accumulation in moss and tree leave samples were possible.

Results: Except for certain flame retardants, PFAS, and ndl-PCB, substances of all other compound classes could be quantified in moss samples of all sites. Concentrations were highest for PAH (40-268 $\left.\mathrm{ng} \mathrm{g}^{-1}\right)$ followed by emerging flame retardants (0.5-7.7 $\mathrm{ng} \mathrm{g}^{-1}$ ), polybrominated diphenyl ethers (PBDE; 0.3-3.7 $\mathrm{ng} \mathrm{g}^{-1}$ ), hexabromocyclododecane (HBCD; 0.3-1.2 $\left.\mathrm{ng} \mathrm{g}^{-1}\right)$, dl-PCB $\left(0.04-0.4 \mathrm{ng} \mathrm{g}^{-1}\right)$ and PCDD/F (0.008-0.06 $\left.\mathrm{ng} \mathrm{g}^{-1}\right)$.

Conclusions: Results show the widespread atmospheric distribution and deposition of organic contaminants across Germany as well as the suitability of moss as bioaccumulation monitor for most of these compound classes. Compared to nearby tree leaf samples, accumulation potential of moss appeared to be higher for pollutants of high octanol-air partition coefficient $\left(\mathrm{K}_{\mathrm{OA}}\right)$ and octanol-water partition coefficient $\left(\mathrm{K}_{\mathrm{OW}}\right)$.
\end{abstract}

Keywords: Biomonitoring, Atmospheric deposition, European moss survey, Halogenated flame retardants, HFR, BFR, Dioxins, Dechlorane Plus, DBDPE

\section{Background}

Monitoring and mapping of atmospheric deposition can be achieved by chemical transport models, technical sampling devices and bioaccumulators such as moss [38]. Due to a lack of roots, mosses receive pollutants rather from the air than from substrates. Pollutant absorbtion through the leaf surface of mosses is facilitated as a waxy

\footnotetext{
*Correspondence: annekatrindreyer@eurofins.de

${ }^{1}$ Eurofins GfA GmbH, Air Monitoring, Stenzelring 14b, 21107 Hamburg, Germany

Full list of author information is available at the end of the article
}

cuticle is missing [60]. Their accumulation is further aided by the high surface to volume ratio of moss [24, 61]. Furthermore, mosses grow in various habitats around the world, even in Polar Regions. Therefore, mosses were and are applied as biomonitors, mainly for nitrogen and heavy metals, but also, although less often, for organic contaminants [7, 19, 20, 24, 31, 43, 44, 46, 50, 52]. Up to now, only few studies were published regarding organic pollutants in moss specimens from Germany $[50,52]$.

Among organic contaminants, persistent organic pollutants (POP) are compounds which were already 
identified as substances of environmental as well as human concern. Besides their persistence, POP are toxic to humans and wildlife, accumulate significantly in living organisms and are transported over long distances [49]. After emissions to the environment, POP become globally distributed, also to regions where they have not been used.

Several chemicals are listed as POP by the Stockholm Convention. These compounds usually share a high degree of halogenation. Among them are some organochlorine pesticides, polychlorinated biphenyls (PCB), polychlorinated dibenzodioxins and -furans (PCDD/F), polybrominated diphenyl ethers (PBDE), hexabromobiphenyl (HBB), hexabromocyclododecane (HBCD) or perfluorooctane sulfonic acid (PFOS). Some POP are unintentionally formed, e.g. PCDD/F by combustion of chlorine-containing substrate or as by-products of industrial processes. Others were intentionally produced for applications as pesticides or industrial chemicals, e.g., PCB as heat exchange fluid or additive in paints and plastics, PFOS as coating additive, or $\mathrm{HBCD}, \mathrm{HBB}$, and PBDE as flame retardants [49]. Production or applications of POP are regulated or restricted; however, market demands often require adequate replacements. For example, bis(2-ethylhexyl)-tetrabromophthalate (BEHTeBP) and 2-Ethylhexyl-2,3,4,5-tetrabromobenzoate $(E H T e B B)$ were used to replace PentaBDE. Decabromodiphenyl ethane (DBDPE) or Dechlorane Plus (DP) were introduced as alternative for DecaBDE $[47,58]$. Although such substitutes might not meet all POP criteria, they often share properties as those substances they were designed to replace and thus might be similarly harmful to the environment or to humans. Therefore, it is not only important to monitor classical POP but also to investigate their substitutes or compounds with (anticipated) POP-like properties.

This study aims for reporting on the determination of selected organic contaminants in moss samples from Germany taken within the framework of the 2015 European moss survey. In the European moss survey programme, since 1990, every 5 years, moss have been sampled at up to about 7300 sites in up to 36 countries, among them Germany. Within the European moss survey programme, sampling, chemical determination of heavy metals (since 1990), nitrogen (since 2005), as well as POP and POP-like substances (since 2010) in moss specimens, quality control and statistical evaluation were conducted according to a harmonized methodology [25]. In Germany, (persistent) organic pollutants in moss samples were to be determined for the first time within this programme in 2015. Therefore, this study aims for the determination of a wide range of organic pollutants to get insight of their extent of accumulation and distribution in moss from Germany. As some of these contaminants were also monitored in tree leaf samples within the German Environmental Specimen Bank (ESB), accumulation in moss should be compared to that in tree leaves. Among the target analytes of this study are polycyclic aromatic hydrocarbons (PAH) including benzo(a)pyrene $(\mathrm{BaP})$ as classical air pollutant with limit value of $1 \mathrm{ng} \mathrm{m}^{-3}$ in ambient air (PM10) [15], PCDD/F, PCB, perfluoroalkyl substances (PFAS), PBDE as well as novel or emerging halogenated flame retardants (HFR) of different substance classes (Dechloranes, brominated aromates, brominated ethers, cyclic HFR). Overall, 120 target analytes were investigated.

\section{Methods}

\section{Sampling}

The moss survey manual [56] recommends the sampling of moss near long-term atmospheric monitoring stations. Within the statistically designed moss monitoring network covering Germany [39], moss samples for the analysis of organic contaminants were taken in November 2016 at eight sites which were located close to areas where tree leaves as bioindicators of atmospheric pollution are routinely sampled within the ESB programme of the German Environment Agency. Tree sampling sites of the German ESB programme represent four different types of terrestrial ecosystems (near-natural, forestry, agricultural, conurbations). Moss sampling sites were chosen so that each of these ecosystem types were represented by at least one moss sampling site. Sites were located at Berchtesgaden/Wimbachtal (BG; Germany's only high mountain national park in the Alps), Bavarian tertiary uplands/Scheyern (SY; part of the southern German basin), Halle/Leipzig-conurbation/Dübener Heide (HL; the chemical triangle of central Germany, formerly eastern Germany), Bornhöved Lakes region/Belauer See (BL; part of the northern German basin and the main water divide between North- and Baltic Sea), Solling/Sievershausen (SO; second highest and largest low mountain range), Harz/Ilsenburg (HA; Germany's largest forest national park) and Saarland (an old-industrialized conurbation) at a forest preserve close to Saarbrücken (SL-SB) and at Waldgassen close to the Warndt recreation area (SL-WA) (Fig. 1, Additional file 1: Table S1). Target moss species were Pleurozium schreberi, Hypnum cupressiforme or Pseudoscleropodium purum (Additional file 1: Table S1). The selection of these moss species as to be sampled by priority is discussed by Fernandez et al. [17], Harmens et al. [26], Holy et al. [28], and Schröder et al. [48]. Moss samples were taken at sites representative of non-urban areas in general accordance to the ICP vegetation moss monitoring manual $[25,56]$. Sampling occurred in a distance of at least $300 \mathrm{~m}$ from main roads, 


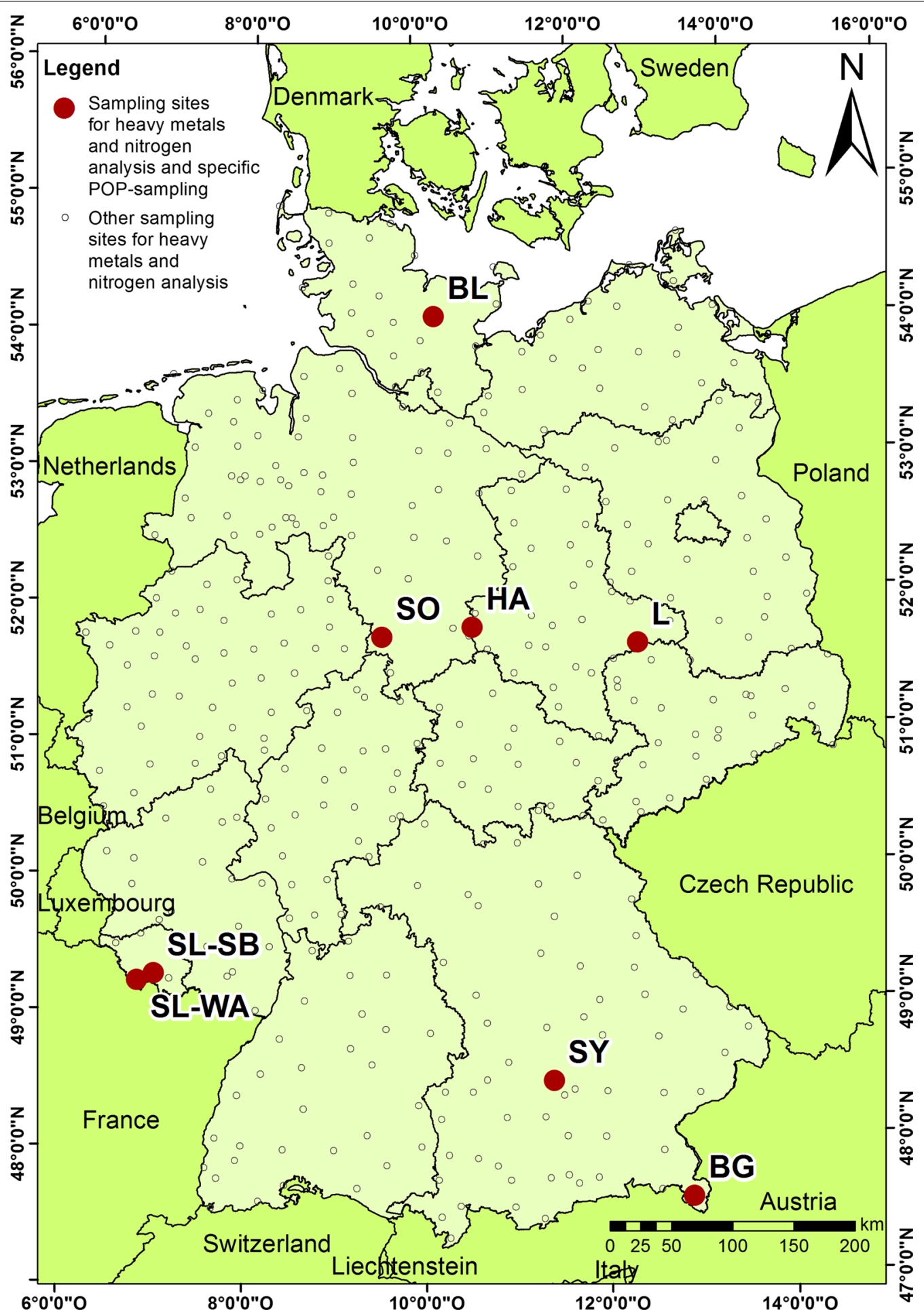

Fig. 1 Location of the moss sampling sites investigated for organic pollutants within the 2015 moss survey. BL Bornhöved Lakes region, SO solling, HA Harz, L Leipzig conurbation, SL-SB Saarland Conurbation close to Saarbrücken, SL-WA Saarland conurbation close to Warndt recreation area, SY Bavarian tertiary uplands close to Scheyern, BG Berchtesgaden 
villages and industries and at least $100 \mathrm{~m}$ away from smaller roads and houses. Sites were situated at least $3 \mathrm{~m}$ away from the nearest tree canopy. Samples were taken using pre-cleaned $2.5 \mathrm{~L}$ wide mouth amber glass bottles. At each site, two of these bottles were filled with moss. Samples were transported and stored between 0 and $4{ }^{\circ} \mathrm{C}$ and in dark until preparation. Storing temperature during transport was monitored.

\section{Sample preparation}

Within 2 weeks after sampling, moss specimens were cleaned off adhering material such as grass, needles, leaves, or soil. Obvious non-target-moss species were also removed. Samples were not washed. Green and green-yellowish moss shoots were separated for analysis using precleaned stainless steel tweezers. Samples were stored at $-20^{\circ} \mathrm{C}$ until drying, homogenisation and further analysis.

\section{Analyses}

For the analysis of the 120 target compounds, several individual analytical procedures were used. The methods are routinely applied analytical procedures according to international guidelines and/or are published elsewhere. Therefore, they are only briefly described here. All target analytes and their abbreviations are listed in the Additional file 1.

\section{PAH}

$3 \mathrm{~g}$ of dried moss were spiked with mass-labelled PAH and extracted using acetone and Soxhlet extraction. After extraction, samples were shaken out with $n, n$-dimethylformic amide and cyclohexane followed by a column chromatography clean-up using silica. The 16 EPA-PAHs were determined by high-resolution gas chromatography coupled to high-resolution mass spectrometry (HRGCHRMS) and quantified using the isotope dilution method [22].

\section{$P C D D / F$ and $P C B$}

Samples were analysed according to a method described by Neugebauer et al. [37]. $2 \mathrm{~g}$ of dried moss were spiked with mass-labelled PCDD/F and extracted using toluene and Soxhlet extraction with at least 60 extraction cycles. Extracts were cleaned-up by multi-layer column chromatography using acidic silica and aluminium oxide. Samples were measured by HRGC-HRMS and quantified using the isotope dilution method. Seventeen 2,3,7,8-substituted PCDD/F congeners, 12 dioxin-like PCB (dl-PCB) and six non dioxin-like PCB (ndl-PCB; PCB 28, 52, 101, 138, 153 und 180) as well as toxicity equivalents were determined.

\section{PFAS}

About $0.5 \mathrm{~g}$ of dried moss were spiked with mass-labelled PFAS and extracted using methanol and ultra-sonication.
Samples were cleaned up using Envicarb. 16 PFAS (PFBS, PFHxS, PFHpS, PFOS, PFDS, PFBA, PFPeA, PFHxA, PFHpA, PFOA, PFNA, PFDA, PFUnA, PFDoA, PFTrA, PFTeA) were determined by high-performance liquid chromatography using electrospray ionisation tandem mass spectrometry (HPLC-ESI-MS/MS) and quantified using the isotope dilution method [18].

\section{$H B C D$ and polybrominated biphenyls (PBB)}

On the basis of a method by Fliedner et al. [18], about $5 \mathrm{~g}$ of dried moss were spiked with mass-labelled HBCD and extracted using toluene and Soxhlet extraction for at least $12 \mathrm{~h}$. After extraction, concentrated sulfuric acid was added for clean-up. Samples were further cleaned by column chromatography using aluminium oxide. The three HBCD isomers $(\alpha, \beta, \gamma-\mathrm{HBCD})$ were determined by HPLC-ESI-MS/MS. Seven PBB (PBB 52, 101, 153, 180, 194, 206 und 209) were determined by gas chromatography coupled to mass spectrometry (GC-MS). All samples were quantified using the isotope dilution method.

PBDE and HFR: Samples were analysed according to a method described by Neugebauer et al. [36]. Briefly, nineteen mass-labelled standards were added to each sample of about $4 \mathrm{~g}$ dried moss prior to accelerated solvent extraction with hexane:dichloromethane 1:1 (v:v). Samples were cleaned-up by a multicolumn procedure involving $\mathrm{Na}_{2} \mathrm{SO}_{4}$ upon 2 g silica, BioBeads SX-3, and Florisil (5\% deactivated). Instrumental detection of 19 HFR (TBA, ATE, BATE, DPTE, BTBPE, EHTeBB, BEHTBP, PBT, HBBz, PBEB, DBDPE, Dec602, Dec603, Dec604, syn-DP, anti-DP, $\mathrm{Cl}_{10}$ anti-DP, $\mathrm{Cl}_{11}$ anti-DP, DPMA) occurred by gas chromatography coupled to tandem mass spectrometry using atmospheric pressure ionization (GC-API-MS/MS). GC-MS was applied to determine 24 PBDE (BDE 17, 28, 47, 49, 66, 71, 77, 85, 99, 100, 119, 126, 138, 153, 154, 156, 183, 184, 191, 196, 197, $206,207,209)$ in a separate run. For the BL site, PBDE and HFR could not be determined as the amount of moss was not high enough to enable this additional analysis.

\section{QA/QC}

Sampling equipment was machine-washed, thoroughly rinsed using methanol, acetone, and hexane and heated to $250{ }^{\circ} \mathrm{C}$ for $12 \mathrm{~h}$. The glassware used for laboratory analysis was machine-washed, heated at $300{ }^{\circ} \mathrm{C}$, and washed with acetone before use. To shield the partially UV-sensitive flame retardants from UV radiation, light exclusion was performed (e.g., by alumina foil, closing shutters, keeping off unnecessary halogen lights, using brown glassware as far as possible). Overall, 78 mass-labelled internal standards were used to correct for losses and irregularities during analysis and measurement. Recovery rates of mass-labelled standards in 
individual samples were generally in the acceptable range as required by EPA 1614A [57] (25-150\%, BDE 209 up to $200 \%$ ) with few exceptions for the most volatile (e.g. $10 \% \mathrm{NapD}_{8}$ ) or highly halogenated target analytes (e.g. $250 \%{ }^{13} \mathrm{C}$ DBDPE). Sample analyses were performed at laboratories which were accredited according to DIN EN ISO IEC 17025 [9] and regularly take part in round robin tests. Except for the PBDE/HFR analysis, all analytical procedures were accredited. The method for the analysis of PBDE and HFR was extensively validated [36]. Certified reference material (EDF2525, T665QC) or similarly materials of known target analyte concentrations as well as blank samples were analysed to check the analytical performance. Method quantification limits (MQL) were calculated on the basis of overall laboratory blank concentrations and signal intensity and varied depending on the used sample amounts. With few exceptions, concentrations in blank samples analysed within the moss sample sequences were below these MQL. Exceptions (selected ndl-PCB and PFAS or PAH) did not impact the findings as the chromatograms of these blank samples did not show any significant influence on the analytical parameters in the range of the sample signals. Instruments used for detection and quantification were regularly checked in terms of separation performance, resolution and sensitivity. Calibrations were performed as multi-point calibrations.

\section{Results and discussion}

\section{Potential constraints}

Even if the moss technique is widely accepted as reliable tool for monitoring and mapping of atmospheric deposition across areas of large spatial extent, there are critical comments, e.g., those compiled by Fernandez et al. [17]. The use of different moss species was discussed as important factor influencing the concentrations of elements in moss and contributing to the variability observed. Additionally, the statistical relevance of sampling site characteristics (moss species, canopy drip effect, etc.) and of their surroundings (land use, atmospheric deposition, etc.) and boundary conditions of data production (sampling, chemical/physical methods, etc.) are important and were evaluated, e.g. for Germany and Europe by Harmens et al. [25], Holy et al. [28], Nickel et al. [40], or Schröder et al. [48]. If and to which significance these factors may also affect organic contaminants accumulated by moss is yet unclear and may be subject of future investigations.

\section{Concentrations of organic pollutants in moss}

Figure 2 depicts an overview about the total concentrations of several groups of organic contaminants in comparison to those of heavy metals. Concentrations of heavy metals were at least one order of magnitude higher than those of the organic compounds. Among the organic pollutants, PAH were observed at highest concentrations followed by flame retardants. In contrast to these substance groups, concentrations of PCDD/F, PCB, and PFAS were much lower or below the MQL. Median concentrations of flame retardants decreased in the order of eBFR, HBCD, BDE209, Dechloranes, and remaining PBDE. In the following, substance classes of the investigated pollutants will be discussed separately.

\section{PAH}

PAH are the most frequently investigated organic contaminants in moss samples. PAH concentrations in investigated moss samples of the present study are given in Fig. 3, Additional file 1: Figure S1 and Tables S5, S6. Total concentrations were between $39.3 \mathrm{ng} \mathrm{g}^{-1}$ dry weight $(\mathrm{dw})$
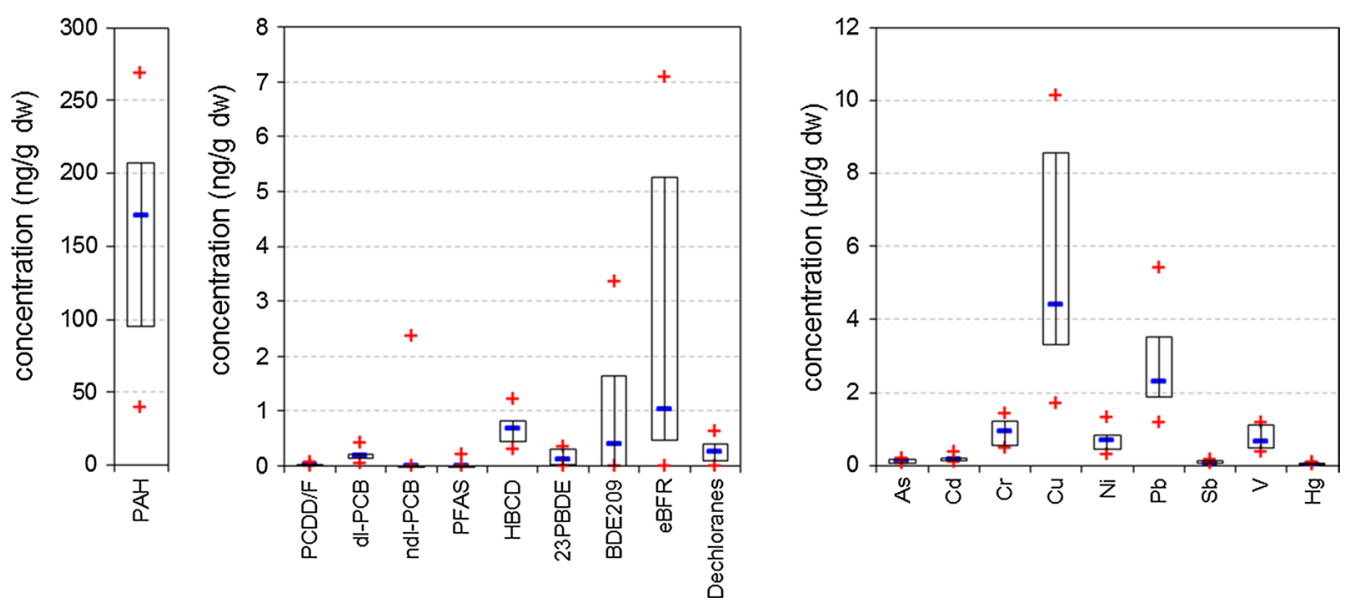

Fig. 2 Overview about total concentrations of groups of organic contaminants in investigated moss samples in comparison to heavy metal concentrations. Note the different scales and units. +: minimum/maximum concentration, -: median concentration, box: 25\%/75\% percentile 


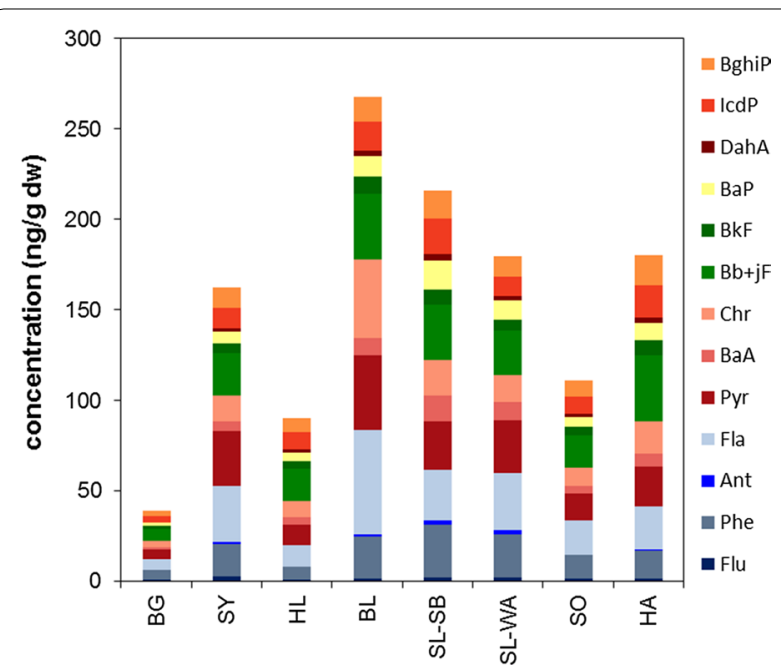

Fig. 3 PAH concentrations (ng g ${ }^{-1} d w$ ) observed in German moss samples

(4.2 $\mathrm{ng} \mathrm{g}^{-1}$ fresh weight (fw)) at BG and $267.8 \mathrm{ng} \mathrm{g}^{-1} \mathrm{dw}$ $\left(47.7 \mathrm{ng} \mathrm{g}^{-1} \mathrm{fw}\right.$ ) at BL. BaP as marker PAH was observed at concentrations between $1.7 \mathrm{ng} \mathrm{g}^{-1} \mathrm{dw}\left(0.2 \mathrm{ng} \mathrm{g}^{-1} \mathrm{fw}\right.$; BG) and $16 \mathrm{ng} \mathrm{g}^{-1} \mathrm{dw}$ (SL-SB) or $2 \mathrm{ng} \mathrm{g}^{-1} \mathrm{fw}$ (BL). German moss concentrations were mostly higher than those observed 2015 in moss samples (Pleurozium schreberi or Hylocomium splendens) in Sweden (15-120 $\mathrm{ng} \mathrm{g}^{-1} \mathrm{dw}$ ) [8]. Total PAH as well as BaP concentrations observed in German moss samples were in the same order as concentrations for PAH ( $\Sigma 13 \mathrm{PAH}$; 149-360 $\mathrm{ng} \mathrm{g}^{-1} \mathrm{dw}$, 100-356 ng g ${ }^{-1} \mathrm{dw}, 98-698 \mathrm{ng} \mathrm{g}^{-1} \mathrm{dw}$, respectively) and $\mathrm{BaP}\left(6-17 \mathrm{ng} \mathrm{g}^{-1} \mathrm{dw}, 2-6 \mathrm{ng} \mathrm{g}^{-1} \mathrm{dw}, 3-47 \mathrm{ng} \mathrm{g}^{-1} \mathrm{dw}\right.$, respectively) observed in Hypnum cupressiforme sampled in 2010 in France, Spain, and Switzerland [20]. They were similarly high compared to concentrations for $\Sigma 16$ PAH observed in Hypnum cupressiforme moss bag samples from an agrarian area in Italy $(\Sigma 16 \mathrm{PAH}$ 60-95 $\mathrm{ng} \mathrm{g}^{-1} \mathrm{dw}$ ) [6] or in moss (several species, mainly Pleurozium schreberi) sampled in Austria ( $\Sigma 16 \mathrm{PAH}$ 81-150 ng g ${ }^{-1} \mathrm{BaP}$ 0.7-4 $\mathrm{ng} \mathrm{g}^{-1}$ ) [62]. They were 1001000 times lower than PAH concentrations observed in B. rutabulum (Hewd.) Schimp at a densely populated and traffic-impacted area in NE Spain in 2011 [5] and 10-100 times lower than $\Sigma 17$ PAH concentrations observed in moss (Hylocomium splendens, Pleurozium schreberi) at an urban site in Poland [10].

Except for Nap, Acy and Ace, all of the remaining target PAH were quantified in moss. The absence of the low molecular weight PAH in all samples may be a result of losses during the analytical process as the recovery rates of corresponding internal standards were quite low. The composition profiles were similar at all sites with $\mathrm{Bb}+\mathrm{jF}$, Fla, Pyr and Phe as dominant compounds (contribution of about $10-20 \%$, each). This is similar to findings in wet-only deposition (precipitation only) at background sites of the German Environment Agency (Westerland, Zingst, Schauinsland, Waldhof, Schmücke) (UBA, pers. communication, 2016). In the same samples, proportions of Phe increased to $25-70 \%$ if the funnel rinse is included. In ambient air samples at the same monitoring sites, Phe contributions of $35-45 \%$ were observed (UBA, pers. communication, 2016). As reviewed by Harmens et al. [24], mosses appear to be most appropriate for measuring environmental chemicals which are particledeposited (i.e. compounds of higher $\log \mathrm{K}_{\mathrm{OW}}$ and $\log \mathrm{K}_{\mathrm{OA}}$ values, also see below). This may also contribute to the underrepresented Phe fraction in moss compared to air or precipitation (including funnel rinse) and is corroborated by Foan et al. [19] reporting bioconcentration factors of PAH in mosses being significantly correlated with $\mathrm{K}_{\mathrm{OW}}$ values.

\section{$P C D D / F$}

$\Sigma 17 \mathrm{PCDD} / \mathrm{F}$ concentrations were also lowest at the BG site $\left(0.8 \mathrm{pg} \mathrm{g}^{-1} \mathrm{fw}, 7.5 \mathrm{pg} \mathrm{g}^{-1} \mathrm{dw}\right)$ and highest at the BL site in northern Germany $\left(10 \mathrm{pg} \mathrm{g}^{-1} \mathrm{fw}, 56 \mathrm{pg} \mathrm{g}^{-1} \mathrm{dw}\right.$, Fig. 4, Additional file 1: Figure S2, Tables S7, S8). Taking toxicity into account, $\mathrm{PCDD} / \mathrm{F}$ TEQ concentrations (without MQL) ranged from $0.024 \mathrm{pg}$ TEQ ${ }_{W H O 2005}$ $\mathrm{g}^{-1} \mathrm{dw}\left(0.003 \mathrm{pg} \mathrm{TEQ}_{\mathrm{WHO} 2005} \mathrm{~g}^{-1} \mathrm{fw}\right)$ to $0.81 \mathrm{pg}$ $\mathrm{TEQ}_{\text {WHO2005 }} \mathrm{g}^{-1} \mathrm{dw}\left(0.12 \mathrm{pg} \mathrm{TEQ}_{\text {WHO2005 }} \mathrm{g}^{-1} \mathrm{fw}\right)$. $\mathrm{PCDD} / \mathrm{F}$ have hardly been analysed in moss. Caraballeira et al. [7] reported PCDD/F concentrations of $10 \mathrm{pg} \mathrm{g}^{-1}$ $\mathrm{dw}$ or $0.3 \mathrm{pg}^{\mathrm{T}} \mathrm{TEQ} \mathrm{g}{ }^{-1} \mathrm{dw}$ (in woodlands) to $422 \mathrm{pg} \mathrm{g}^{-1} \mathrm{dw}$ or 34 pg TEQ $\mathrm{g}^{-1} \mathrm{dw}$ (close to a landfill) in Pseudoscleropodium purum from Spain. Recently, Danielsson et al. [8] observed PCDD/F concentrations in Swedish moss samples (Pleurozium schreberi or Hylocomium splendens)

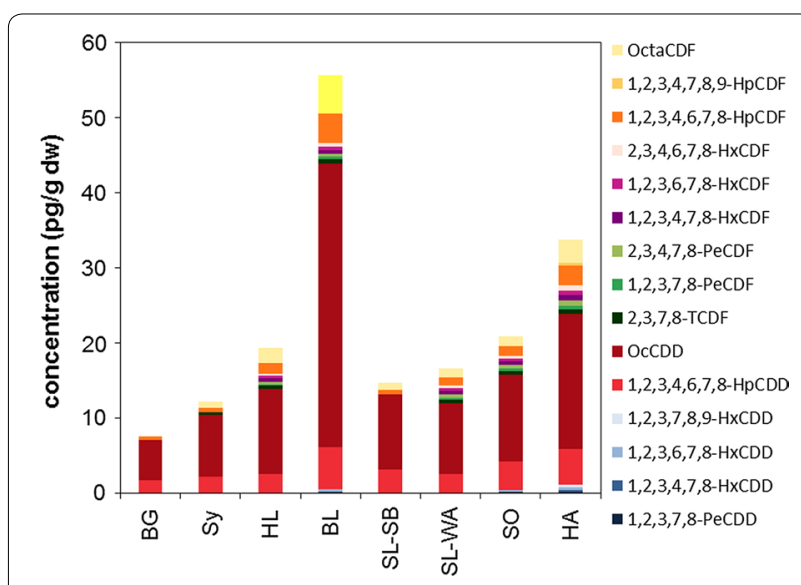

Fig. 4 PCDD/F concentrations (pg g ${ }^{-1} \mathrm{dw}$ ) observed in German moss samples 
from 0.0001 to 0.57 pg TEQ ${ }_{W H O 2005} g^{-1} \mathrm{dw}$. Thus, maximum TEQ-based PCDD/F moss concentrations were similarly high in Sweden and Germany; whereas, lowest TEQ values were about ten times lower in Sweden. $\mathrm{PCDD} / \mathrm{F}$ have been analysed in lichens slightly more frequently, e.g. recently by Augusto et al. [3] in the Mediterranean region with average $\mathrm{PCDD} / \mathrm{F}$ concentrations of $35 \mathrm{pg} \mathrm{g}^{-1}$ in 2011 to $150 \mathrm{pg} \mathrm{g}^{-1}$ in 2000.

With 55-70\%, OCDD dominated the PCDD/F profiles followed by $1,2,3,4,6,7,8-\mathrm{HpCDD}$, OCDF, and $1,2,3,4,6,7,8-\mathrm{HpCDF}$. In contrast to samples SL-SB, BY and $B G$, where only these three congeners were quantified, remaining samples also comprised other PCDD/F congeners, however, at low concentrations close to the MQL. 2,3,7,8-TCDD was not detected in any sample. The rather similar PCDD/F profiles in moss suggest a widespread source-distant PCDD/F contamination at the investigated sites at slightly differing but low levels which resembled typical atmospheric background profiles [45].

\section{dl-PCB}

Total concentrations of dioxin-like PCB in investigated moss samples varied by a factor of ten between the sites with a range from $41 \mathrm{pg} \mathrm{g}^{-1} \mathrm{dw}\left(4.4 \mathrm{pg} \mathrm{g}^{-1} \mathrm{fw}\right)$ to $423 \mathrm{pg} \mathrm{g}^{-1} \mathrm{dw}\left(40.6 \mathrm{pg} \mathrm{g}^{-1}\right.$ fw, Fig. 5, Additional file 1: Figure S3, Tables S9, S10). Concentrations were lowest at BG and highest at the Saarland site SL-SB. At the remaining sites, concentrations of dl-PCB did not differ much and were between $137 \mathrm{pg} \mathrm{g}^{-1} \mathrm{dw}$ and $216 \mathrm{pg} \mathrm{g}^{-1}$ $\mathrm{dw}$. Concentrations on the basis of TEQ (w/o MQL) were between $0.002 \mathrm{pg} \mathrm{TEQ}_{\mathrm{WHO} 2005} \mathrm{~g}^{-1} \mathrm{dw}$ (BG) and $0.22 \mathrm{pg}$ $\mathrm{TEQ}_{\mathrm{WHO} 2005} \mathrm{~g}^{-1} \mathrm{dw}$ (HA). Except for SL-SB, TEQ values

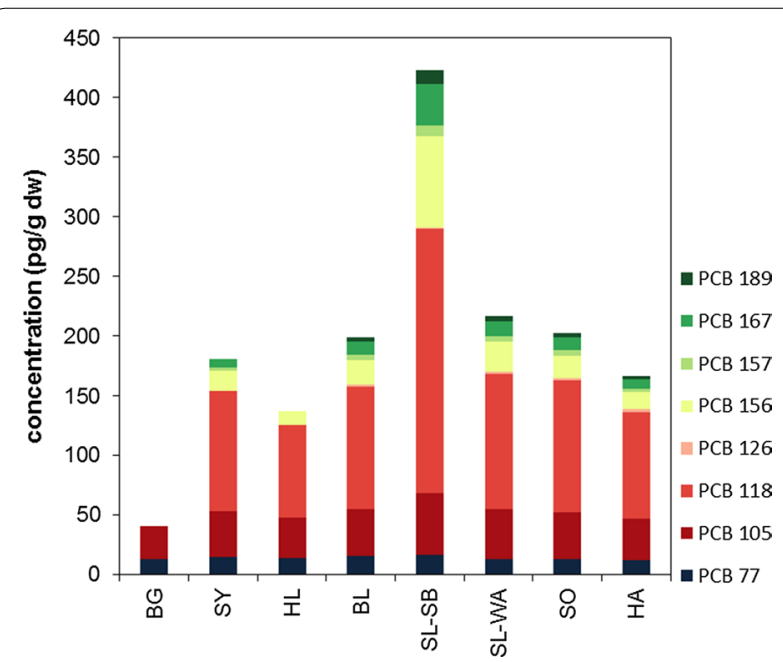

Fig. 5 dl-PCB concentrations ( pg g $^{-1} \mathrm{dw}$ ) observed in German moss samples resulting from dl-PCB contamination were lower than those from PCDD/F contamination. Similar to PCDD/F, maximum dl-PCB concentrations in German moss samples were in the same order, minimum concentrations up to a factor of hundred higher than concentrations observed in recent investigations on moss (Pleurozium schreberi or Hylocomium splendens) in Sweden (0.000030.073 pg TEQ ${ }_{\text {WHO2005 }} \mathrm{g}^{-1} \mathrm{dw}$ ).

Except for BG where only two dl-PCB were quantified, dl-PCB profiles in moss samples were quite similar to PCB 118 as dominating compound (50-55\%) followed by PCB 105 (12-25\%), PCB 156 (9-18\%) and PCB 77 (4-10\%). At BG, only PCB 77 and PCB 105 were observed. The predominance of PCB 118 and elevated contributions of the other above-mentioned dl-PCB was also observed in German ambient air and deposition samples, although with higher PCB 118 proportions compared to moss samples [45].

\section{ndl-PCB}

In all but one sample which was located in the Saarland conurbation (SL-SB), ndl-PCB concentrations were below the MQL (Additional file 1: Tables S11, S12). At the SL-SB site, only three ndl-PCB (PCB 138, PCB 153, PCB $180)$ were quantified at individual concentrations ranging from 0.6 to $1 \mathrm{ng} \mathrm{g}^{-1} \mathrm{dw}\left(0.06-0.1 \mathrm{ng} \mathrm{g}^{-1} \mathrm{fw}\right)$. In general, method quantification limits of ndl-PCB are higher than those of dl-PCB due to the ubiquitous presence of ndl$\mathrm{PCB}$, also in laboratory blank samples. Therefore, dl-PCB have been quantified whereas ndl-PCB usually were not. Still, the low frequency of quantification was surprising, as marker PCB are common pollutants in German forest soils (up to $106 \mathrm{ng} \mathrm{g}^{-1} \mathrm{dw}$ ), particularly in western Germany [1]. Similar to our results, concentrations of marker PCB (0.19-0.84 $\mathrm{ng} \mathrm{g}^{-1} \mathrm{dw}$, mainly PCB 101, PCB 153) were mostly close to or below the MQL in Swedish moss (Pleurozium schreberi or Hylocomium splendens) [8]. Levels for $\Sigma 25$ PCB observed in moss (Drepanocladus aduncus) from Svalbard were in the same order (0.43$1.16 \mathrm{ng} \mathrm{g}^{-1}$ ) with Mono- to HexaCB being the dominant homologues [63]. Thüns [53] observed ndl-PCB in Sphagnum-dominated peat bogs of Eastern Canada; however, significant post depositional mobility of $\mathrm{PCB}$ on longer time scales was described which hampered the use of these peatlands as PCB deposition archives. Such mobility may have also influenced PCB accumulation in recent moss samples.

\section{PFAS}

PFAS were generally not quantified $\left(\mathrm{MQL}<0.15 \mathrm{ng} \mathrm{g}^{-1}\right.$ $\mathrm{dw})$ in investigated moss samples with the exception of PFOS (0.2 $\left.\mathrm{ng} \mathrm{g}^{-1} \mathrm{dw} ; 0.04 \mathrm{ng} \mathrm{g}^{-1} \mathrm{fw}\right)$ in the Bornhöved 
Lakes region. Similarly, Danielsson et al. [8] did not find PFAS in Swedish moss. PFAS have been found in precipitation in Germany and elsewhere, e.g. [11, 61] and due to the phase-out of long-chain PFAS a shift of composition to short-chain PFAS (among other compounds) was already noted in European environmental archives [30]. Therefore, it is not surprising that Falk et al. [16] observed mainly PFBA $\left(1.5-5 \mathrm{ng} \mathrm{g}^{-1}\right)$ in German tree leave samples. PFOA $\left(<0.07-0.2 \mathrm{ng} \mathrm{g}^{-1}\right)$ and PFOS $\left(<0.07-0.2 \mathrm{ng} \mathrm{g}^{-1}\right)$ were also often detected, however, at lower concentrations. Likewise, Yeung et al. [61] found mainly short-chain PFAS in recently taken rain water samples. However, exactly these short-chain PFAS have been found to be highly mobile and to be only little retained in soil or Sphagnum-dominated peatlands [13]. Thus, mosses do not appear to be good bioindicators for atmospheric PFAS pollution.

\section{Flame retardants}

Figure 6 shows concentrations of flame retardants. Individual graphs have been arranged to scale to facilitate comparisons. It becomes obvious that one single compound, DBDPE, dominates the investigated flame-retardant substance spectra. The DBDPE proportion was lowest in Bavarian samples (SY, BG) and highest at one Saarland site (SL-SB). Similar to DP, which was found to be much less prominent in German moss samples, DBDPE was reported to replace DecaBDE $[47,58]$, the second most dominant substance in the investigated samples. HBCD was observed at third highest concentrations. Compared to these three substances, remaining individual PBDE, $\mathrm{PBB}$ or emerging flame retardants were observed at concentrations being much lower or below the respective MQL (Additional file 1: Tables S15-S18, Figures S5-S7).

Concentrations of $\Sigma 23$ PBDE (i.e. w/o deca-BDE 209) were between $0.027 \mathrm{ng} \mathrm{g}^{-1} \mathrm{dw}\left(0.003 \mathrm{ng}^{-1} \mathrm{fw}\right)$ at BG and $0.29 \mathrm{ng} \mathrm{g}^{-1} \mathrm{dw}\left(0.043 \mathrm{ng} \mathrm{g}^{-1} \mathrm{fw}\right)$ at HA. BDE 209 concentrations ranged from $<0.95 \mathrm{ng} \mathrm{g}^{-1} \mathrm{dw}\left(<0.1 \mathrm{ng} \mathrm{g}^{-1} \mathrm{fw}\right)$ at BG to $3.35 \mathrm{ng} \mathrm{g}^{-1} \mathrm{dw}\left(0.5 \mathrm{ng} \mathrm{g}^{-1} \mathrm{fw}\right)$ at HA. Besides BDE 209, main BDE contributions were observed for BDE 99, BDE 47 and BDE 100. Other PBDE occasionally quantified close to the MQL were BDE 28, BDE 49, BDE 66, BDE 85, BDE 153, BDE 154, BDE 183, BDE 206 and BDE 207. Besides the strong DecaBDE signal, the pattern of remaining PBDE was similar to the congener pattern

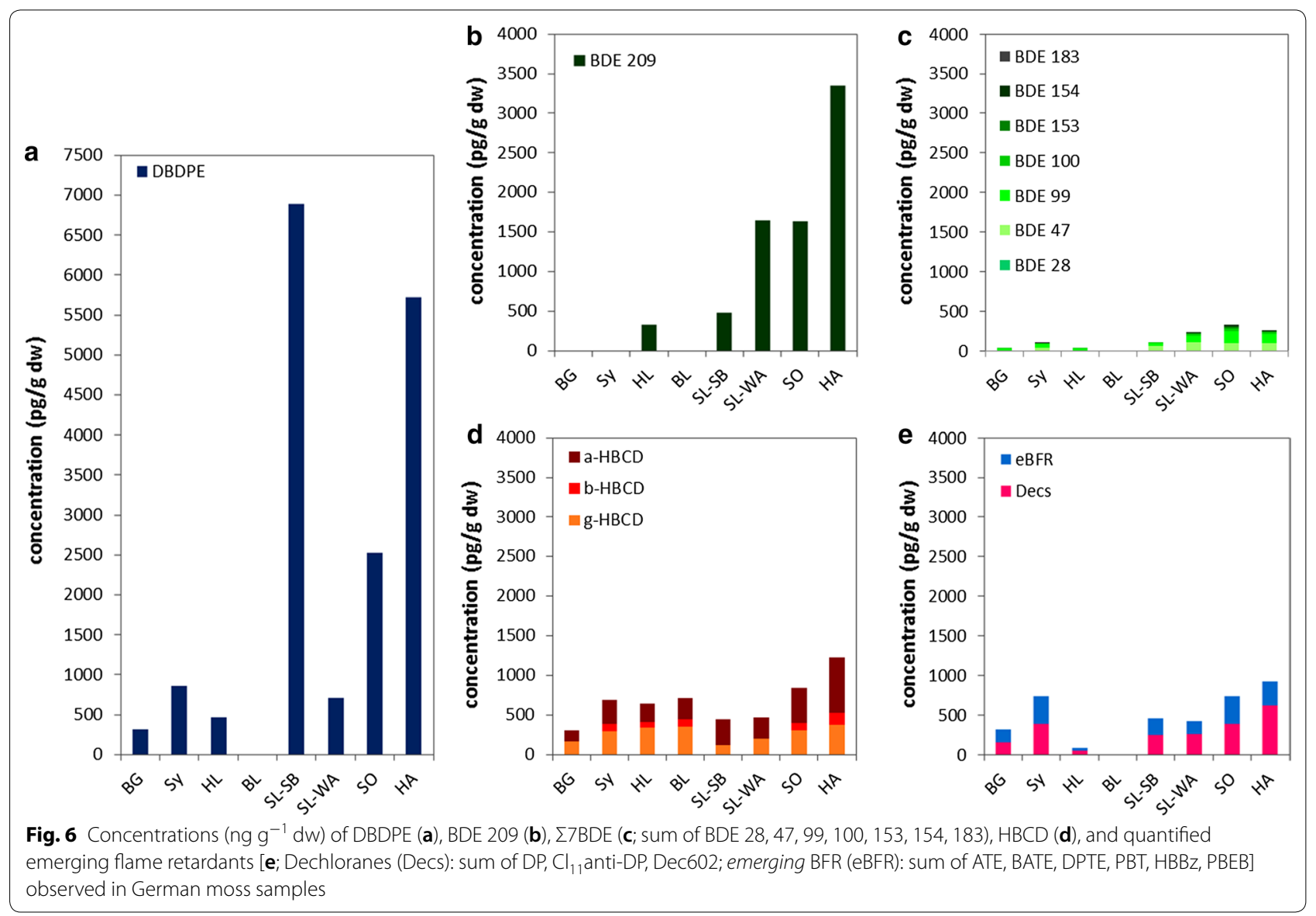


in a technical penta-mixture that is characterized by a dominance of BDE 99 and BDE 47 followed by minor contributions of BDE 100, BDE 153 and BDE 154 [32]. Of eight PBDE investigated in moss samples (Pleurozium schreberi or Hylocomium splendens) from Sweden, TetraBDE 47 was nearly exclusively observed at concentrations of $0.06-0.46 \mathrm{ng} \mathrm{g}^{-1} \mathrm{dw}$ [8]. For Norwegian moss samples (Hylocomium splendens), $\Sigma 7 \mathrm{PBDE}$ concentrations of 0.03-0.34 $\mathrm{ng} \mathrm{g}^{-1} \mathrm{dw}$ and BDE 209 concentrations of $0.05-1.6 \mathrm{ng} \mathrm{g}^{-1} \mathrm{dw}$ were published [32]. With a dominance of BDE 209 and major contributions of BDE 47 and BDE 99, PBDE profiles were similar to German moss samples. The presence of PBDE in mosses at very remote locations was shown by Wang et al. [59] ( $212 \mathrm{PBDE}$ w/o BDE 209: $0.122 \mathrm{ng} \mathrm{g}^{-1} \mathrm{dw}$, mainly BDE 47, BDE 28 and BDE 99) and Zhu et al. [63] ( $\Sigma$ 13PBDE w/o BDE 209: $0.119 \mathrm{ng} \mathrm{g}^{-1} \mathrm{dw}$, mainly BDE 47, BDE 99, BDE 183; Drepanocladus aduncus) at Svalbard, by Zhu et al. [64] at the Tibetan plateau ( 213 PBDE: $0.16 \mathrm{ng} \mathrm{g}^{-1} \mathrm{dw}$, mainly BDE 183; Pottiaceae, Hypnaceae) and by Kim et al. [29] at the south Shetland Islands, Antarctica ( 1 19PBDE: 0.003$0.07 \mathrm{ng} \mathrm{g}^{-1} \mathrm{dw}$; mainly BDE 47, BDE 99; Sanionia uncinata, Andreaea depressinervis).

Emerging brominated flame retardants were quantified in all samples. DBDPE concentrations ranged from $0.3 \mathrm{ng} \mathrm{g}^{-1} \mathrm{dw}\left(0.04 \mathrm{ng} \mathrm{g}^{-1} \mathrm{fw}\right)$ at BG to $6.9 \mathrm{ng} \mathrm{g}^{-1} \mathrm{dw}$ at SL-SB ( $1 \mathrm{ng} \mathrm{g}^{-1} \mathrm{fw}$ at HA). Other eBFR quantified in almost all samples although at lower concentrations were DPTE $\left(<0.1 \mathrm{ng} \mathrm{g}^{-1} \mathrm{dw} /<0.015 \mathrm{ng} \mathrm{g}^{-1} \mathrm{fw}\right.$ at L to $0.26 \mathrm{ng} \mathrm{g}^{-1} \mathrm{dw}$ at SY/0.04 $\mathrm{ng} \mathrm{g}^{-1} \mathrm{fw}$ at HA) as well as ATE, BATE, HBBz, and PBT. TBA was only occasionally observed. BTBPE, EHTeBB, BEHTBP, and PBEB were not observed in any sample. Without DBDPE, the composition of emerging brominated flame retardants was quite similar between the moss samples with major contributions of DPTE (Additional file 1: Figure S7). The dominance of DBDPE and major contributions of DPTE were also observed in tree leave samples of nearby sites [12]. Among other HFR, DBDPE was observed in moss samples taken at Faroes (0.14$0.34 \mathrm{ng} \mathrm{g}^{-1} \mathrm{dw}$; Hylocomium splendens, [47]). In contrast to our study, Schlabach et al. [47] also observed PBEB (0.004-0.006 $\mathrm{ng} \mathrm{g}^{-1} \mathrm{dw}$ ) and BTBPE (0.06$\left.0.15 \mathrm{ng} \mathrm{g}^{-1} \mathrm{dw}\right)$ in these moss samples. Compared to German moss samples, concentrations of $\mathrm{HBBz}$ were in the same order, those of PBT by a factor of 10 lower.

Of chlorinated flame retardants, DP was observed in all samples $\left(0.05 \mathrm{ng} \mathrm{g}^{-1} \mathrm{dw} / 0.01 \mathrm{ng} \mathrm{g}^{-1} \mathrm{fw}\right.$ at HL to $0.6 \mathrm{ng} \mathrm{g}^{-1} \mathrm{dw} / 0.1 \mathrm{ng} \mathrm{g}^{-1} \mathrm{fw}$ at HA). Dec602 and the DP degradation product $\mathrm{Cl}_{11}$-antiDP were only occasionally found. Dec603, Dec604, DPMA and $\mathrm{Cl}_{10}$-antiDP were not quantified in any sample. DP concentrations in moss of the South Shetland Islands, Antarctica were between 0.001 and $2.4 \mathrm{ng} \mathrm{g}^{-1} \mathrm{dw}$ (Andreaea depressinervis, Sanionia uncinata; [29]). These authors also quantified Dec602 at concentrations below $0.0025 \mathrm{ng} \mathrm{g}^{-1} \mathrm{dw}$. Na et al. [35] reported DP concentrations of $0.0014 \mathrm{ng} \mathrm{g}^{-1}$ $\mathrm{dw}$ in moss collected from Svalbard. The fraction of the anti-DP-isomer $(f($ anti $)=[$ anti-DP $] /[\Sigma D P])$ is often used to investigate stereo selective enrichment or degradation of one or the other DP isomer because the final DP product contains syn-DP and anti-DP in a certain ratio (f(anti):0.6-0.8) [27, 51, 55]. In the German moss samples, $f$ (anti) values were in the narrow range between 0.74 and 0.79 ( 0.76 on average) which does not indicate a significant selective enrichment. Moss $f$ (anti) values were similar to those observed in tree leave samples from nearby sites ( 0.72 on average [12]) but showed less variance. They were higher than values reported for European air masses investigated in 2008 ( $f$ (anti) in sample English Canal: 0.63; [34]).

HBCD was also quantified in all moss samples. Similar to other contaminants, lowest concentrations were observed at BG (0.03 ng g $\left.{ }^{-1} \mathrm{fw}, 0.3 \mathrm{ng} \mathrm{g}^{-1} \mathrm{dw}\right)$. Highest concentrations were found at HA $\left(0.18 \mathrm{ng} \mathrm{g}^{-1} \mathrm{fw}\right.$, $1.2 \mathrm{ng} \mathrm{g}^{-1} \mathrm{dw}$ ). Interestingly, HBCD concentrations in the Saarland conurbation (SL-SB, SL-WA) were rather low whereas concentrations for other flame retardants belonged to the highest that were observed (see below). In Sweden and Norway, HBCD was not detected in any moss sample [8]. Kim et al. [29] observed between 0.002 and $2.4 \mathrm{ng} \mathrm{g}^{-1} \mathrm{dw}$ HBCD in mosses (Andreaea depressinervis, Sanionia uncinata) of South Shetland Islands, Antarctica. HBCD was also observed in lichen from the Tibetan plateau (0.14 $\left.\mathrm{ng} \mathrm{g}^{-1} \mathrm{dw}\right)$ but not in moss [64]. All of the three HBCD isomers were observed in German moss samples. $35-73 \%$ of the HBCD composition was made of $\alpha-\mathrm{HBCD}, 27-53 \%$ of $\gamma-\mathrm{HCBD}$ and up to $12 \%$ of $\beta$-HBCD. At sites of low HBCD concentrations, levels of $\beta$-HBCD were below the MQL. Thus, similar to findings in fauna [4], $\alpha-\mathrm{HBCD}$ appeared to be preferentially accumulated in moss compared to technical mixtures, where its presence is only $3-30 \%$. This is in contrast to findings of Zhu et al. [64] who reported an HCBD composition in lichen being close to that of technical mixtures.

\section{Sources}

For the evaluation of pollutant sources, source regions or transport pathways correlation analyses, multivariate statistics and fingerprinting by comparing profiles or certain diagnostic ratios (DR) are often used. The low number of sampling sites/samples of the pilot study presented limits the applications and informative value of such approaches for our data set. Thus, within the Moss 
Survey 2020, the number of moss sampling sites for POP analyses should be increased based on respective statistics derived by the presented pilot study 2015 .

Correlation analyses on analyte concentrations (Spearman, $p<0.05$ ) show strong positive and significant relationships for most, particularly high molecular weight $\mathrm{PAH}$ which indicates similar sources, probably combustion processes (see below). With few rather scattered exceptions, no such relationships were observed between individual PAH and other compounds pointing at different sources or pathways as those of PAH. Individual $\mathrm{PCDD} / \mathrm{F}$ concentrations were correlated significantly to each other as well as individual dl-PCB. However, no relationships were observed between individual PCDD/F and individual dl-PCB indicating different sources (e.g. combustion-related sources (PCDD/F and dl-PCB), pigments (dl-PCB, ndl-PCB), technical PCB mixtures (dl$\mathrm{PCB}$, ndl-PCB) [33]), different transport behaviour and/ or ad/absorption characteristics of the compounds or just the limitations of the small data set. Only few significant correlations existed between individual PBDE or HFR. PentaBDE were correlated as well as the polybrominated ethers DPTE and BATE or highly brominated and chlorinated flame retardants DBDPE, DP or BDE209 (Additional file 2).

Quass et al. [45] statistically investigated PCDD/F deposition and ambient air data from Germany. PCDD/F profiles in moss were similar to a typical background site reference profile for PCDD/F in ambient air where OCDD dominates the profile (52\%) followed by $1,2,3,4,6,7,8$ HpCDD (19\%), OCDF (5.2\%), and 1,2,3,4,6,7,8-HpCDF
(5.7\%). A general background site reverence profile for deposition samples was not reported due to a higher site-specific variance of PCDD/F composition; however, individual investigated deposition samples were characterized by the above-mentioned main congeners with an OCDD dominance that was, similarly to moss samples of the present study, more pronounced than in air samples. Thus, PCDD/F in moss probably originated from atmospheric background PCDD/F contamination.

Diagnostic ratios of individual PAH or PAH groups are often used to distinguish different $\mathrm{PAH}$ sources, since PAH emission profiles depend on conditions during PAH generation $[10,14,42,54]$. PAH diagnostic ratios have to be interpreted with caution. Depending on the physical chemical properties of individual $\mathrm{PAH}$, their reactivity or (photo/oxidant) degradability, DR values may change during environmental transport or phase transitions $[14,54]$. Dvorska et al. [14] concluded that DR are better predictors under conditions of limited availability of oxidants and when the reaction time (and thus distance) is short between source and receptor areas. Tobiszewski and Namiesnik [54] reported that the Fla/(Fla + Pyr) and $\mathrm{IcdP} /(\mathrm{IcdP}+\mathrm{BghiP})$ ratios are more conservative than ratios of $\mathrm{Ant} /(\mathrm{Ant}+\mathrm{Phe})$ and $\mathrm{BaA} /(\mathrm{BaA}+\mathrm{Chr})$, which are more sensitive to photodegradation. Selected diagnostic ratios observed in German moss samples and their assignment to potential sources referring to Tobiszewski and Namiesnik [54] are depicted in Fig. 7 and Additional file 1: Table S23. According to these ratios, $\mathrm{PAH}$ in German mosses rather originated from mixed combustion processes. Uncertainties involved with this
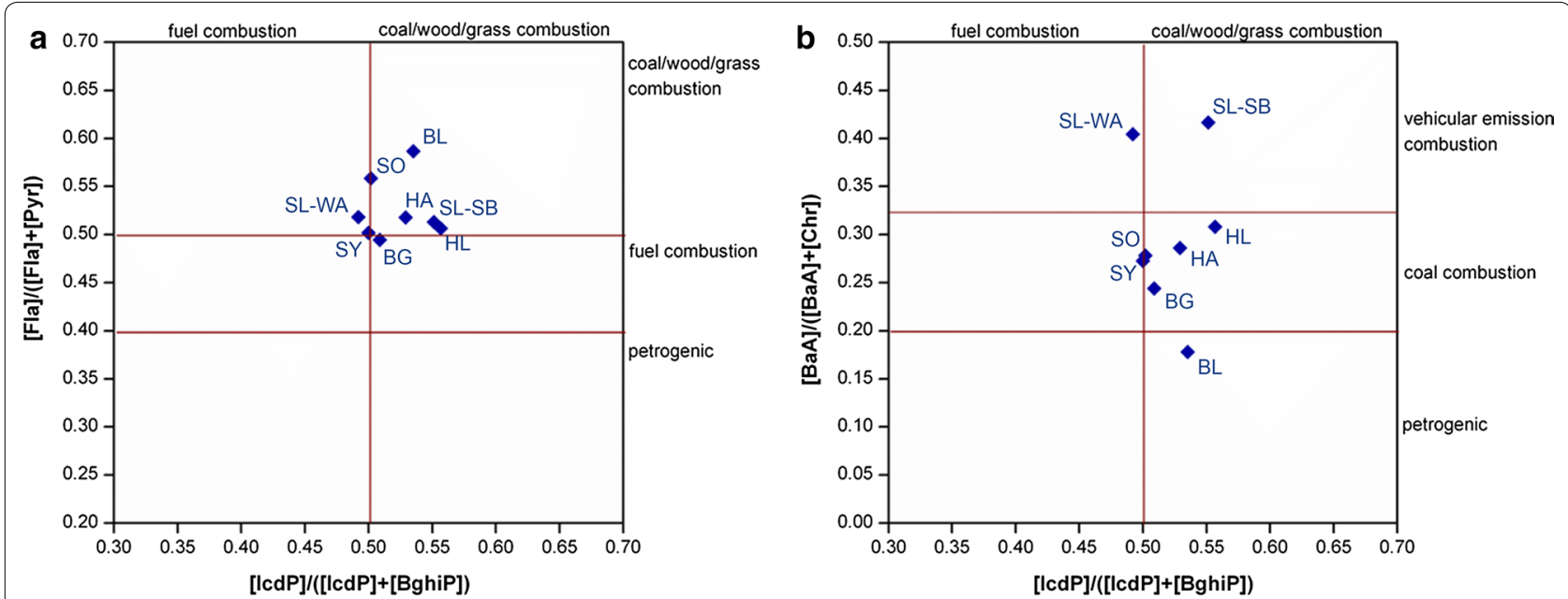

Fig. $7 \mathrm{PAH}$ cross plots for the diagnostic concentration ratios of a $\mathrm{IcdP} /(\mathrm{IcdP}+\mathrm{BghiP})$ and $\mathrm{Fla} /(\mathrm{Fla}+\mathrm{Pyr})$ and $\mathbf{b} \mathrm{lcdP} /(\mathrm{IcdP}+\mathrm{BghiP}$ and BaA/ (BaA + Chr). Diagnostic ratios and assignment of DR values from [54] 
method become obvious looking at the DR for the BL site where two DR point at combustion-related PAH sources $(\mathrm{Fla} /(\mathrm{Fla}+\mathrm{Pyr})=0.59, \quad \operatorname{IcdP} /(\mathrm{IcdP}+\mathrm{BghiP})=0.54)$ whereas one points at petrogenic $\mathrm{PAH}$ sources $(\mathrm{BaA} /$ $(\mathrm{BaA}+\mathrm{Chr})=0.18)$.

\section{Comparison of moss to tree leaf samples}

Certain PAH and flame retardants were also determined in tree leave samples within the monitoring programme of the German ESB [12, 21]. As moss sampling was conducted close to some of the tree sampling sites, values of deciduous tree leaves (Fagus sylvatica, Populus nigra) and 1-year-old coniferous shoots (Pinus sylvestris, Picea abies) sampled in 2015 or 2016 can be compared to those observed in moss within the limitations due to the low number of samples.

In general, $\mathrm{PAH}$ and flame-retardant concentrations in moss, tree leaves and tree shoots were in the same order (Additional file 1: Figures S8, S9) showing that investigated mosses and tree leaves/shoots are generally suited biomonitors of atmospheric pollution of these contaminants. Few exceptions were observed for Phe, low molecular weight PAH at the conurbation sites HL, SL-WA and SL-SB, for TetraBDE and PentaBDE at HL and for DBDPE at SL-SB and HA. Individual PAH or flame-retardant concentrations in moss and tree leaves or shoots were not significantly correlated (Spearman, $p<0.05$ ) which may have resulted from the small number of samples, different accumulation periods as well as small-scale differences regarding the locations of sampling sites. Accumulation of three-ring PAH, particularly Phe, increased in the order moss $<$ deciduous leaves $<$ coniferous shoots. In contrast, $\mathrm{BaA}$, five- and six-ring $\mathrm{PAH}$ concentrations decreased in the order moss $>$ deciduous leaves $\geq$ coniferous shoots. Observed differences for PAH were mostly significant $(U$-test, $p<0.05)$. For four-ring PAH, concentrations did not differ between moss and tree samples. These results are corroborated by findings of Oishi [42] who similarly described pine needles preferentially accumulating low molecular weight PAH. Except for syn-DP and anti-DP in moss and coniferous trees, HFR concentrations were not significantly different $(U$-test, $p<0.05)$.

Differences expressed as ratios between concentrations observed in moss and concentrations observed in trees averaged over the investigated sites indicate a dependence on $\log \mathrm{K}_{\mathrm{OW}}$ and $\log \mathrm{K}_{\mathrm{OA}}$, i.e. the higher $\log$ $\mathrm{K}_{\mathrm{OW}}$ or $\log \mathrm{K}_{\mathrm{OA}}$ values the more is accumulated in moss relative to tree leaves or shoots (Fig. 8). Observed correlations were significant (Spearman, $p<0.05$ ). Similarly to $\mathrm{PAH}$, average moss/tree concentration ratios for flame retardants increased with increasing $\log \mathrm{K}_{\mathrm{OW}}$ and $\log$ $\mathrm{K}_{\mathrm{OA}}$ values (Fig. 8), although with flatter slopes and ratios being lower for deciduous trees than for conifers. This may be due to specific physical, chemical or morphological leaf characteristics, substance-specific properties, as well as emission properties with regard to the sampling time and/or accumulation period in the respective plant matrix. The exact mechanism for the substance classrelated differences cannot be resolved for the present data set.

\section{Conclusion}

Several organic contaminants $(\mathrm{PAH}$, several PCDD/F, $\mathrm{dl}-\mathrm{PCB}$ and flame retardants) were detected in moss sampled across Germany in the framework of a pilot study integrated into the European Moss Survey 2015. This pilot study shows the widespread spatial distribution as well as the suitability of moss as biomonitor for these pollutants. Limitations may, however, exist for the accumulation potential of PFAS. Compared to nearby tree leaf samples, accumulation potential of mosses appeared to be higher for pollutants of high $\log \mathrm{K}_{\mathrm{OA}}$ or $\mathrm{K}_{\mathrm{OW}}$. Concentrations between the investigated sites did not differ by more than a factor of 10 (DBDPE 20). Lowest concentrations were usually observed at Berchtesgaden, the most pristine of investigated sites located in the German Alps. Elevated concentrations were often observed at the Saarland conurbation and the Harz, for $\mathrm{PCDD} / \mathrm{F}$ and PAH also at the Bornhöved Lakes region, indicating potential source regions close to these areas. With the exception of dl-PCB and DBDPE at one Saarland site, contamination was not very pronounced at investigated conurbation areas. Given that quantified concentrations of some compounds were close to the respective MQLs and that MQLs, thus, had a strong influence on the compositions, substance class profiles were quite similar between the samples and indicated rather diffuse sources. Within the Moss Survey 2020, the number of moss sampling sites for POP analyses 

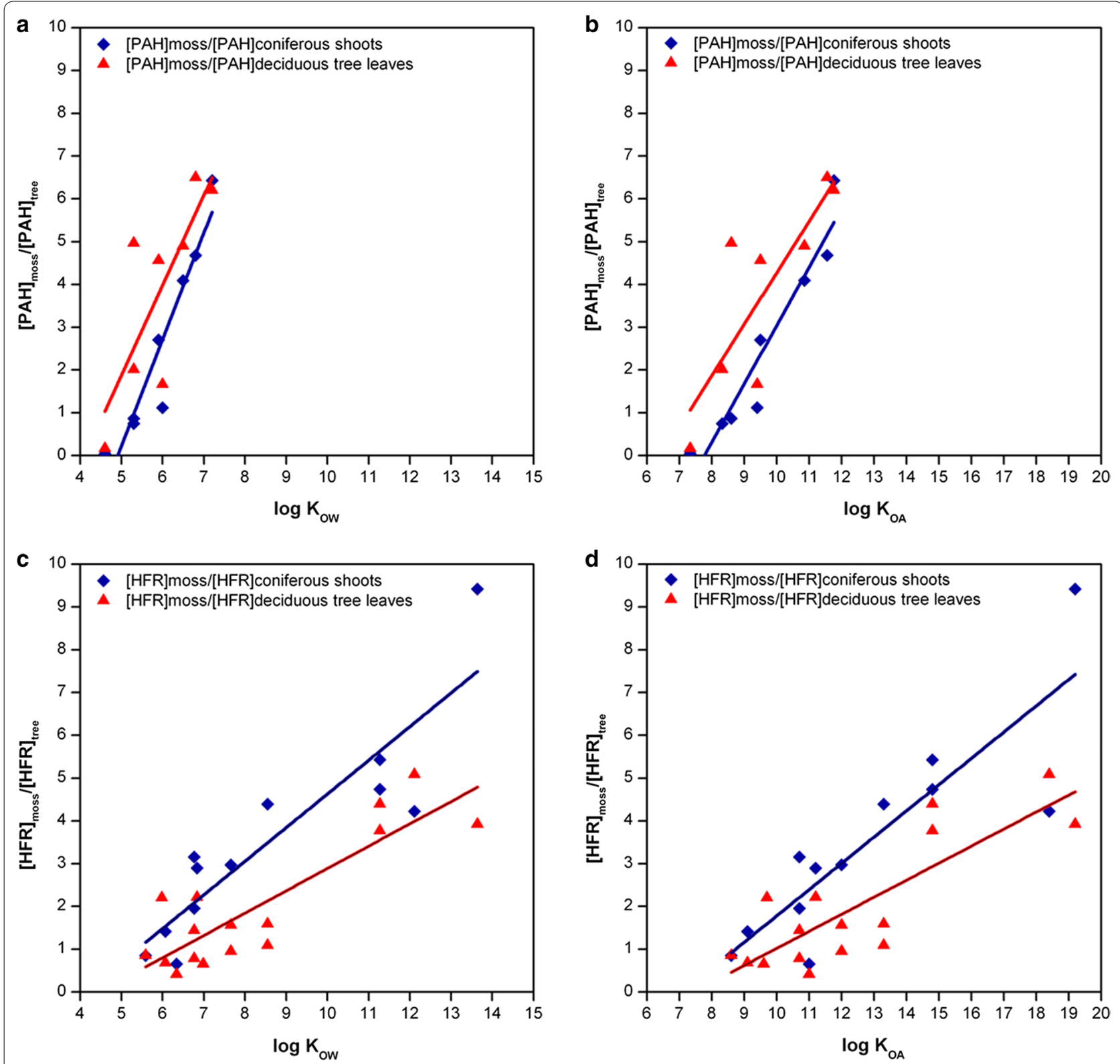

Fig. 8 Averaged moss-tree leaf/shoot concentration ratios of PAH $(\mathbf{a}, \mathbf{b})$ and flame retardants $(\mathbf{c}, \mathbf{d})$ in relation to log $\mathrm{K}_{\mathrm{OW}}$ and log $\mathrm{K}_{\mathrm{OA}}$. PAH included were those PAH that had been analysed in moss samples as well as in coniferous shoot and deciduous leaf samples of the German ESB (Phe, Fla, Pyr, $\mathrm{BaA}, \mathrm{Chr}, \mathrm{BaP}, \mathrm{IcdP}, \mathrm{BghiP})$. Log $\mathrm{K}_{\mathrm{OW}}$ and log $\mathrm{K}_{\mathrm{OA}}$ values for PAH from [41, 54], for flame retardants from [2, 23]

should be increased based on respective statistics derived by the presented pilot study 2015 .

\section{Additional files}

Additional file 1. Additional figures and tables.

Additional file 2. Spearman correlation.

\section{Abbreviations}

BEHTeBP: bis(2-ethylhexyl)-tetrabromophthalate; DBDPE: decabromodiphenyl ethane; DecaBDE: decabromo diphenyl ether; dl-PCB: dioxin-like PCB; DP: Dechlorane Plus; eBFR: emerging brominated flame retardants; EHTeBB: 2-ethylhexyl-2,3,4,5-tetrabromobenzoate; ESB: Environmental Specimen Bank: GC-API-MS/MS: gas chromatography coupled to tandem mass spectrometry using atmospheric pressure ionization; GC-MS: gas chromatography coupled to mass spectrometry; HBB: hexabromobiphenyl; HBCD: hexabromocyclododecane; HFR: halogenated flame retardants; HPLC-ESI-MS/MS: high performance liquid chromatography using electrospray ionisation; HRGCHRMS: high-resolution gas chromatography coupled to high-resolution mass 
spectrometry; Koa: octanol-air partition coefficient; Kow: octanol-water partition coefficient; MQL: method quantification limit; ndl-PCB: non dioxin-like PCB; PAH: polycyclic aromatic hydrocarbons; PBB: polybrominated biphenyls; PBDE: polybrominated diphenyl ether; PCB: polychlorinated biphenyls; PCDD/F: polychlorinated dibenzodioxins and -furans; PentaBDE: pentabromo diphenyl ether; PFAS: polyfluorinated alkyl substances; PFOS: perfluorooctane sulfonic acid; POP: persistent organic pollutants.

\section{Authors' contributions}

AD managed the chemical analyses, performed data analyses and wrote the manuscript. SN and WS managed and coordinated the 2015/16 German moss monitoring project and prepared the manuscript. All authors read and approved the final manuscript.

\section{Author details}

1 Eurofins GfA GmbH, Air Monitoring, Stenzelring 14b, 21107 Hamburg, Germany. ${ }^{2}$ University of Vechta, P.O.B. 1553, 49364 Vechta, Germany.

\section{Acknowledgements}

We are thankful to Dietmar Teuber for sampling, to Gabriela Enachi, Oliver Jädtke and Azimsah Akgün for their help preparing the samples as well as to Gudrun Schütze. We acknowledge the laboratory staff of Eurofins GfA Lab Service, particularly Nina Lohmann and Frank Neugebauer.

\section{Competing interests}

The authors declare that they have no competing interests.

\section{Availability of data and materials}

The datasets supporting the conclusions of this article are included within the article and its additional file.

\section{Consent for publication}

Not applicable.

\section{Ethics approval and consent to participate} Not applicable.

\section{Funding}

The authors wish to thank the German Environment Agency for funding (FKZ $3715632120)$.

\section{Publisher's Note}

Springer Nature remains neutral with regard to jurisdictional claims in published maps and institutional affiliations.

\section{Received: 14 August 2018 Accepted: 21 October 2018}

\section{Published online: 12 November 2018}

\section{References}

1. Aichner B, Bussian B, Lehnik-Habrink P, Hein S. Levels and spatial distribution of persistent organic pollutants in the environment: a case study of German forest soils. Environ Sci Technol. 2013;47:12703-14.

2. AMAP (2018) Arctic Monitoring and Assessment Programme 2018. https://chemicals.amap.no/chemicals/2-4-6-tribromophenyl-2-3-dibro mopropyl-ether/ Accessed 21 Jan 2018

3. Augusto S, Pinho P, Santos A, Botelho MJ, Palma-Oliveira J, Branquinho C (2015) Declining trends of PCDD/Fs in lichens over a decade in a Mediterranean area with multiple pollution sources. Sci Total Environ 508:95-100

4. Baron E, Gimenez J, Verborgh P, Gauffier P, De Stephanis R, Eljarrat E, Barcelo D (2015) Bioaccumulation and biomagnification of classical flame ratardants, related halogenated natural compounds and alternative flame retardans in three delphinids from Southern European waters. Environ Pollut 203:107-115

5. Bustamante J, LiÃro O, Arrizabalaga I, Carrero JA, Arana G, de Diego A (2015) Sample pretreatment to differentiate between bioconcentration and atmospheric deposition of polycyclic aromatic hydrocarbons in mosses. Chemosphere 122:295-300
6. Capozzi F, Giordano S, Di Palma A, Spagnuolo V, De Nicola F, Adamo P (2016) Biomonitoring of atmospheric pollution by moss bags: discriminating urban-rural structure in a fragmented landscape. Chemosphere 149:211-218

7. Carballeira A, Angel Fernandez J, Aboal JR, Real C, Couto JA (2006) Moss: a powerful tool for dioxin monitoring. Atmos Environ 40(30):5776-5786

8. Danielsson, H., Hansson, K., Potter, A., Friedrichsen, J. and Brorström-Lundén, E., 2016. Persistent organic pollutants in Swedish msses. IVL Swedish Environmental Research Institute, http://www.ivl.se, C118

9. DIN EN ISO IEC 17025 (2007) General requirements for the competence of testing and calibration laboratories. Beuth Verlag, Berlin

10. Dolegowska, S. and Migaszewski, Z.M., 2011. PAH concentrations in the moss species Hylocomium splendens (Hedw.) B.S.G. and Pleurozium schreberi (Brid.) Mitt. from the Kielce area (south-central Poland). Ecotoxicology and Environmental Safety, 74(6): 1636-1644

11. Dreyer A, Matthias V, Weinberg I, Ebinghaus R (2010) Wet deposition of poly- and perfluorinated compounds in Northern Germany. Environ Pollut 158(5):1221-1227

12. Dreyer A, Neugebauer F, Rüdel H, Klein R, Lohmann N, Rauert C, Koschorreck J (2018) Halogenated flame retardants in tree samples applied as bioindicators for atmospheric pollution. Chemosphere 208:233-240

13. Dreyer A, Thuens S, Kirchgeorg T, Radke M (2012) Ombrotrophic peat bogs are not suited as natural archives to investigate the historical atmospheric deposition of perfluoroalkyl substances. Environ Sci Technol 46(14):7512-7519

14. Dvorska A, Lammel G, Klanova J (2011) Use of diagnostic ratios for studying source apportionment and reactivity of ambient polycyclic aromatic hydrocarbons over Central Europe. Atmos Environ 45(2):420-427

15. European Union (2005) Directive 2004/107/EC of the European parliament and of the council of 15 December 2004 relating to arsenic, cadmium, mercury, nickel and polycyclic aromatic hydrocarbons in ambient air. Off J Eur Union 23:3-16

16. Falk S, Stahl T, Rüdel H, Biegel-Englert A, Koschorreck J. submitted. Patterns, temporal and spatial trends of perfluoroalkyl acids (PFAA) in terrestrial ecosystems over the last three decades. Environ Poll

17. Fernandez JA, Boquete MT, Carballeira A, Aboal JR (2015) A critical review of protocols for moss biomonitoring of atmospheric deposition: sampling and sample preparation. Sci Total Environ 517:132-150

18. Fliedner A, Lohmann N, Rüdel H, Teubner D, Wellmitz J, Koschorreck J (2016) Current levels and trends of selected EU Water Framework Directive priority substances in freshwater fish from the German environmental specimen bank. Environ Pollut 216:866-876

19. Foan L, Domercq M, Bermejo R, Santamaria JM, Simon V (2015) Mosses as an integrating tool for monitoring PAH atmospheric deposition: comparison with total deposition and evaluation of bioconcentration factors. A year-long case-study. Chemosphere 119:452-458

20. Foan L, Leblond S, Thöni L, Raynaud C, Santamaria JM, Sebilo M, Simon $\checkmark$ (2014) Spatial distribution of PAH concentrations and stable isotope signatures $\left(I^{\prime} 13 C, I^{\prime} 15 \mathrm{~N}\right)$ in mosses from three European areas $\hat{a} \epsilon^{\prime \prime}$ Characterization by multivariate analysis. Environ Pollut 184:113-122

21. German Environment Agency, 2017. Umweltprobenbank des Bundes. http://www.umweltprobenbank.de Accessed 18 Nov 2017

22. Götz R, Bauer $\mathrm{O}$, Friesel $P$, Herrmann $T$, Jantzen $E$, Kutzke $M$, Lauer R, Päpke O, Roch K, Roweder U, Schwarz R, Sievers S, Stachel B (2007) Vertical profile of PCDD/Fs, dioxin-like PCBs, other PCBs, PAHs, chlorobenzenes, DDX, organotin compounds and chlorinated ethers in dated sediment/ soil cores from flood-plains of the river Elbe, Germany. Chemosphere 67:592-603

23. Gustavsson J, Ahrens L, Nguyena MA, Josefsson S, Wiberg K (2017) Development and comparison of gas chromatography-massspectrometry techniques for analysis of flame retardants. J Chromatogr A 1481:116-126

24. Harmens H, Foan L, Simon V, Mills G (2013) Terrestrial mosses as biomonitors of atmospheric POPs pollution: a review. Environ Pollut 173:245-254

25. Harmens H, Mills G, Hayes F, Norris D, Sharps K (2015) Twenty eight years of ICP vegetation. An overview of its activities. Annal Bot 5:31-43

26. Harmens $\mathrm{H}$, Schröder W, Zechmeister HG, Steinnes E, Frontasyeva M (2015) A critical review of protocols for moss biomonitoring of atmospheric deposition: Sampling and sample preparation. Sci Total Environ 517:132-150 
27. Hoh E, Zhu L, Hites RA (2006) Dechlorane plus, a chlorinated flame retardant, in the Great Lakes. Environ Sci Technol 40(4):1184-1189

28. Holy M, Pesch R, Schröder W, Harmens H, Ilyin I, Alber R, Aleksiayenak Y, Blum O, Coşkun M, Dam M, Temmerman LD, Fedorets N, Figueira R, Frolova M, Frontasyeva M, Goltsova N, Miqueo LG, Grodzińska K, Jeran Z, Korzekwa S, Krmar M, Kubin E, Kvietkus K, Larsen M, Leblond S, Liiv S, Magnússon S, Maňkovská B, Mocanu R, Piispanen J, Rühling Å, Santamaria J, Steinnes E, Suchara I, Thöni L, Turcsányi G, Urumov V, Wolterbeek B, Yurukova L, Zechmeister HG (2009) First thorough identification of factors associated with $\mathrm{Cd}, \mathrm{Hg}$ and $\mathrm{Pb}$ concentrations in mosses sampled in the European Surveys 1990, 1995, 2000 and 2005. J Atmos Chem 63:109-124

29. Kim J-T, Choi Y-J, Barghi M, Yoon Y-J, Kim J-H, Kim JH, Chang Y-S (2018) Occurrence and distribution of old and new halogenated flame retardants in mosses and lichens from the South Shetland Islands Antarctica. Environ Pollut 235:302-311

30. Kirchgeorg T, Dreyer A, Gabrieli J, Kehrwald N, Sigl M, Schwikowski M, Boutron C, Gambaro A, Barbante C, Ebinghaus R (2013) Temporal variations of perfluoroalkyl substances and polybrominated diphenyl ethers in alpine snow. Environ Pollut 178:367-374

31. Lim TB, Xu R, Tan B, Obbard JP (2006) Persistent organic pollutants in moss as bioindicators of atmospheric pollution in Singapore 64. Chemosphere 64(4):596-602

32. Mariussen E, Steinnes E, Breivik K, Nygard T, Schlabach M, Kalas JA (2008) Spatial patterns of polybrominated diphenyl ethers (PBDEs) in mosses, herbivores and a carnivore from the Norwegian terrestrial biota. Sci Total Environ 404(1):162-170

33. Megson D, Jones R, Johnson G, Brown T, Sandau C (2018) How many PCBs are there in the environment and where do they come from? Dioxin 2018. Krakow, Poland

34. Moeller A, Xie Z, Sturm R, Ebinghaus R (2010) Large-scale distribution of dechlorane plus in air and seawater from the Arctic to Antarctica. Environ Sci Technol 44(23):8977-8982

35. Na G, Wei W, Zhou S, Gao H, Ma X, Ge L, Bao C, Yao Z, Qiu L (2015) Distribution characteristics and indicator significance of Dechloranes in multi-matrices at Ny-Alesund in the Arctic. J Environ Sci 28:8-13

36. Neugebauer F, Dreyer A, Lohmann N, Koschorreck J (2018) Determination of halogenated flame retardants by GC-API-MS/MS and GCEl-MS: a multi-compound multi-matrix method. Anal Bioanal Chem 410(4):1375-1387

37. Neugebauer F, Schröter-Kermani C, Päpke O, Steeg W (2011) Analytical experiences with the German Environmental Specimen Bank: time trends of PCDD/F and DL_PCB in bream (Abramis brama) caught in German rivers. Organohalogen Compd 73:1340-1343

38. Nickel S, Schröder W (2017) Integrative evaluation of data derived from biomonitoring and models indicating atmospheric deposition of heavy metals. Environ Sci Pollut Res 24:11919-11939

39. Nickel S, Schröder W (2017) Reorganisation of a long-term monitoring network using moss as biomonitor for atmospheric deposition in Germany. Ecol Ind 76:194-206

40. Nickel S, Schröder W, Wosniok W, Harmens H, Frontasyeva MV, Alber R, Aleksiayenak J, Barandovski L, Blum O, Danielsson H, de Temmermann L, Dunaev AM, Fagerli H, Godzik B, Ilyin I, Jonkers S, Jeran Z, Karlsson P, LebIond S, Liiv S, Mankovska B, Martínez-Abaigar J, Piispanen J, Poikolainen J, Popescu IV, Qarri F, Radnovic D, Santamaria JM, Schaap M, Skudnik M, Špiri Z, Stafilov T, Steinnes E, Stihi C, Suchara I, Thöni L, Uggerud HT, Zechmeister HG (2017) Modelling and mapping heavy metal and nitrogen concentrations in moss in 2010 throughout Europe by applying Random Forests models. Atmos Environ 156:146-159

41. Odabasi M, Cetin E, Sofuoglu A (2006) Determination of octanol-air partition coefficients and supercooled liquid vapor pressures of PAHs as a function of temperature: application to gas-particle partitioning in an urban atmosphere. Atmos Environ 40(34):6615-6625

42. Oishi Y (2018) Comparison of moss and pine needles as bioindicators of transboundary polycyclic aromatic hydrocarbon pollution in central Japan. Environ Pollut 234:330-338

43. Orliński R (2002) Multipoint moss passive samplers assessment of urban airborne polycyclic aromatic hydrocarbons: concentrations profile and distribution along Warsaw main streets. Chemosphere 48:181-186

44. Ötvös E, Kozák IO, Fekete J, Sharma VK, Tuba Z (2004) Atmospheric deposition of polycyclic aromatic hydrocarbons (PAHs) in mosses (Hypnum cupressiforme) in Hungary. Sci Total Environ 330:89-99
45. Quass U, Meyer J, Kuhlbusch T (2016) Zuordnung und Quantifizierung der Dioxineinträge auf dem Luftpfad mittels Betrachtung der emissionsseitigen und immissionsseitigen Kongenerenmuster. Umweltbundesmat Texte 23. https://www.umweltbundesamt.de/publikationen/zuordnungquantifizierung-der-dioxineintraege-auf

46. Schaffers AP, Sykora KV (2000) Reliability of Ellenberg indicator values for moisture, nitrogen and soil reaction: a comparison with field measurements. J Veg Sci 11:225-244

47. Schlabach M, Remberger M, Brorström-Lundén E, Norström K, Kaj L, Andersson H, Herzke D, Borgen A, Harju M (2011) Brominated flame retardants (BFR) in the nordic environment. TemaNord 528

48. Schröder W, Holy M, Pesch R, Harmens H, llyin I, Steinnes E, Alber R, Aleksiayenak Y, Blum O, Coşkun M, Dam M, Temmerman LD, Frolova M, Frontasyeva M, Miqueo LG, Grodzińska K, Jeran Z, Korzekwa S, Krmar M, Kubin E, Kvietkus K, Leblond S, Liiv S, Magnússon S, Maňkovská B, Piispanen J, Rühling Å, Santamaria J, Spiric Z, Suchara I, Thöni L, Urumov V, Yurukova L, Zechmeister HG (2010) Are cadmium, lead and mercury concentrations in mosses across Europe primarily determined by atmospheric deposition of these metals? J Soils Sediments 10:1572-1584

49. Stockholm Convention (2018) http://chm.pops.int, Accessed 21 Jan 2018

50. Storm C (1993) Passives Biomonitoring organischer Schadstoffe mit Moosen im Rahmen des Ökologischen Wirkungskatasters Baden-Württemberg. Proj.Nr. L 23-91.02 der LfU, 124 S., Freiburg

51. Sverko E, Tomy GT, Reiner EJ, Li Y-F, McCarry BE, Arnot JA, Law RJ, Hites RA (2011) Dechlorane plus and related compounds in the environment: a review. Environ Sci Technol 45(12):5088-5098

52. Thomas W (1981) Entwicklung eines Immissionsmesssystems für PCA, Chlorkohlenwasserstoffe und Spurenmetalle mittels epiphytischer Moose, angewandt auf den Raum Bayern. Bayreuther geowissenschaftliche Arbeiten, 3

53. Thüns S (2014) Application of the peat archive as tool in environmental chemistry. Dissertation University of Bayreuth: https://epub.uni-bayreuth. de/2048/1/Diss\%20final\%202015-03.pdf

54. Tobiszewski M, Namiesnik J (2011) PAH diagnostic ratios for the identification of pollution emission sources. Environ Pollut 162:110-119

55. Tomy GT, Pleskach K, Ismail N, Wittle DM, Helm PA, Sverko E, Zaruk D, Marvin CH (2007) Isomers of dechlorane plus in lake winnipeg and lake ontario food webs. Environ Sci Technol 41(7):2249-2254

56. UNECE ICP VEGETATION (2015) Heavy metals, nitrogen and POP in European mosses: 2015 survey monitoring manual. https://icpvegetation.ceh. ac.uk/publications/documents/MossmonitoringMANUAL-2015-17.07.14. pdf

57. US EPA (2010) Method 1614A_Brominated Diphenyl Ethers in Water, Soil, Sediment, and Tissue by HRGC/HRMS. United States Environmental Protection Agency, May 2010

58. Vorkamp K, Riget FF (2014) A review of new and current-use contaminants in the Arctic environment: evidence of long-range transport and indications of bioaccumulation. Chemosphere 111:379-395

59. Wang Z, Na G, Ma X, Ge L, Lin Z, Yao Z (2015) Characterizing the distribution of selected PBDEs in soil, moss and reindeer dung at Ny Alesund of the Arctic. Chemosphere 137:9-13

60. Wu Q, Wang X, Zhou Q (2014) Biomonitoring persistent organic pollutants in the atmosphere with mosses: performance and application. Environ Int 66:28-37

61. Yeung LWY, Stadey C, Mabury SA (2017) Simultaneous analysis of perfluoroalkyl and polyfluoroalkyl substances including ultrashort-chain C2 and $\mathrm{C} 3$ compounds in rain and river water samples by ultra performance convergence chromatography. J Chromatogr A 1522:78-85

62. Zechmeister H, Kropik M, Moser D, Denner M, Hohenwallner D, HanusIllnar A, Scharf S, Riss A, Mirtl M (2016) Moosmonitoring in Österreich, Aufsammlung 2015. Umweltbundesamt Österreich, http://www.umwel tbundesamt.at/fileadmin/site/publikationen/REP0595.pdf, REP-0595

63. Zhu C, Li Y, Wang P, Chen Z, Ren D, Ssebugere P, Zhang Q, Jiang G (2015) Polychlorinated biphenyls (PCBs) and polybrominated biphenyl ethers (PBDEs) in environmental samples from Ny-Ãesund and London Island, Svalbard, the Arctic. Chemosphere 126:40-46

64. Zhu N, Schramm K-W, Wang T, Henkelmann B, Fu J, Gao Y, Wang Y, Jiang G (2015) Lichen, moss and soil in resolving the occurrence of semi-volatile organic compounds on the southeastern Tibetan Plateau, China. Sci Total Environ 518-519:328-336 